\title{
Fabrication of Inorganic Monolith Coated with Gold Nanoparticles for Protein Purification
}

\author{
Eman Alzahrani, Ahmed M Fallatah \\ Chemistry Department, Faculty of Science, Taif University, Taif, KSA \\ *E-mail: em-s-z@hotmail.com, a.fallatah.11@ hotmail.com
}

doi: $10.20964 / 2019.02 .15$

Received: 2 September 2018 / Accepted: 4 November 2018 / Published: 5 January 2019

This work aims at developing a new technique used to fabricate porous inorganic monolith using pore surface improved coverage with gold nanoparticles (AuNPs) that has the capacity of preconcentrating proteins that has effectiveness of high preconcentration. The advantage of incorporating inorganic monolith with gold nanoparticles is getting high effective isolation of target analytes as a result of helpful features of surface area. Initially, the inorganic monolith was fabricated using the sol-gel process. The fabricated monolithic material was then chemically modified using 3-mercaptopropyltrimethoxysilane, and subsequently AuNPs immobilization on the surface of the inorganic monolith was performed. The materials that were synthesized were studied with the use of diverse methods such as FT-IR analysis, UV-Vis spectroscopy, EDAX and TEM analysis. As a fabricated sorbent for preconcentration of standard proteins (hemoglobin and pepsin), the AuNPs modified inorganic monolith was applied and its performance was contrasted with bare inorganic monolith. The fabricated AuNPs modified inorganic monolith would be a powerful sorbent for protein preconcentration from a real sample that is complicated.

Keywords: preconcentration, standard proteins, inorganic monolith, sorbent media, and gold nanoparticles.

\section{$\underline{\text { FULL TEXT }}$}

(C) 2019 The Authors. Published by ESG (www.electrochemsci.org). This article is an open access article distributed under the terms and conditions of the Creative Commons Attribution license (http://creativecommons.org/licenses/by/4.0/). 